\title{
Molecular Detection of Enteric Viruses in Treated Wastewater, Surface and Groundwater in Errachidia Region, Morocco
}

\author{
Rachid Bounagua ${ }^{1,2}$, Hicham El Rhaffouli ${ }^{2 *}$, Fatima El Boukhrissi ${ }^{3}$, Naoufel Rahmatallah ${ }^{1}$, Zakaria Yassin ${ }^{2}$, Hind El
} Kasraoui $^{2}$, Abdelillah Laraqui ${ }^{4}$, Coralie Portelli-Clerc ${ }^{5}$, Yassine Sekhsoukh ${ }^{4}$, Ouafaa Fassi-Fihri ${ }^{1}$

\author{
${ }^{1}$ Hassan II Agronomic and Veterinary Institute, Unit of Microbiology Immunology and Contagious Diseases, Department of Pathology \\ and Veterinary Public Health, Rabat, Morocco \\ ${ }^{2}$ Royal Armed Forces' Health Services, veterinary division, Rabat, Morocco \\ ${ }^{3}$ Sidi Mohamed Ben Abdellah University, Faculty of Medecine et de Pharmacy, Fes, Morocco \\ ${ }^{4}$ University Mohammed V, Faculty of Medicine and Pharmacy, Mohammed V Military Teaching Hospital, Biosafety Level 3 and \\ Research Laboratory, Rabat, Morocco \\ ${ }^{5} 28$ th Veterinary Group, Paris, France
}

DOI: $10.36348 /$ sipm.2021.v06i01.006
*Corresponding author: Hicham El Rhaffouli

\section{Abstract}

One-year surveillance for enteric viruses in raw sewage, treated water and groundwater near of near effluents from the wastewater treatment plant (WWTPs) of Errachidia, Morocco from March 2018 to April 2019. samples were carried out in 1-liter bottles sterile propylene at the levels of raw water, treated water, and effluent water at several points and well water. Virus concentration was performed according to an end point filtration on cellulose nitrate filter of $0.2 \mu \mathrm{m}$ pore. A total of 108 was screened for Enterovirus (EV), Rotavirus (RV), Norovirus (NoV) and Hepatitis A (HAV) using a real time RT-PCR technique. The study shows a persistence of the contamination of the treated water, effluents and groundwater by EV, NoV and RV. Contrariwise, no HAV was detected in any sample performed during the study period. Detection rate for EV ranged from $100 \%$ for surface water to $50 \%$ for groundwater. For NoV detection rate ranged from $100 \%$ to $33 \%$ for surface and groundwater respectively while RV was detected in $8 \%$ to $42 \%$ in surface water and $0 \%$ to $8 \%$ in groundwater. These results suggest that enteric virus contamination of wadi Ziz negatively impact on their microbiological quality since they are used for irrigation and drinking intake, which exposes the population of the region to constant risk of acute gastroenteritis, especially in children.

Keywords: Enteric virus, Enterovirus, Rotavirus, Norovirus, Hepatitis A virus, WWTPs, Errachidia, Morocco.

Copyright () 2021 The Author(s): This is an open-access article distributed under the terms of the Creative Commons Attribution 4.0 International License (CC BY-NC 4.0) which permits unrestricted use, distribution, and reproduction in any medium for non-commercial use provided the original author and source are credited.

\section{INTRODUCTION}

Global warming and population increase are major causes of water resource scarcity. This situation is accentuated in countries with water stress particularly in arid area like Errachidia region in Morocco. The use of unconventional water resources such as treated wastewater is a very important alternative for these regions. However, the use of wastewater will pose a risk of virus pollution of the environment and subsequent affects viral transmission [2]. Indeed, the discharge of insufficiently treated wastewater effluent is the most common source of pathogenic enteric viruses in aquatic environments [3]. More than 150 types of enteric viruses are eliminated in human stools and urine and are responsible for several diseases, especially nonbacterial gastroenteritis [4, 5]. Human Enterovirus (HE), Rotaviruses (RV), Norovirus (NoV) and Hepatitis A (HAV) viruses are among the most sought-after viruses in raw and treated wastewater [9, 10]. These viruses are highly resistant in the outdoor environment, can persist in purification treatments, and then be found in surface waters, coastal waters or food $[6,7]$. On the other hand, documenting viral prevalence and diversity in sewage may be a useful method for monitoring viruses circulating in the community [8]. In morocco, only one published study [7] was performed to monitor the presence of enteroviruses and adenoviruses in treated wastewater in humid region. However, there is no data concerning arid regions or other enteric viruses. Thus, in this work we investigated the presence of four major pathogenic group of enteric viruses: HEV, RV, $\mathrm{NoV}, \mathrm{HAV}$ in treated wastewater and in groundwater near effluents from the wastewater treatment plant (WWTPs) of Errachidia city. 


\section{MATERIALS AND METHODS}

The Errachidia WWTPs operates according to a protocol of aerated lagoons. It is located three kilometers south-east of the city; Its GPS coordinates

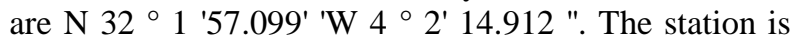
designed to receive a nominal flow rate of $7520 \mathrm{~m} 3 /$ day by 2020. It comprises 10 basins and rejects the treated water in the $\mathrm{Ziz}$ wadi bed. Bacteriological quality of treated water complies with agricultural reuse [11] but no studies on virus contamination have been conducted.

\section{SAMPLES}

During the study period (March 2018 to April 2019), 12 samples of raw sewage were collected at the entrance to the WWTPs (1 samples / month) and 12 samples of treated wastewater were collected at the water output of the station. An additional 3 sampling points were identified along the wadi Ziz at 200 (P1), 2000(P2) and 5000m (P3) from the station's effluent outfall were a total of 36 samples were performed. To evaluate de viral contamination of groundwater, 48 samples were collected from 4 wells (W1, W2, W3, W4) located near the effluent of the treatment plant (Figure-1). these are shallow wells (12-22m) and very influenced by the wadi ziz with fairly significant piezometic variations $( \pm 5 \mathrm{~m})$ depending on the flow of the wadi.

All samples were collected in 1-liter sterile propylene bottles and quickly transported to the laboratory in an isothermal tank with cooling blocks.

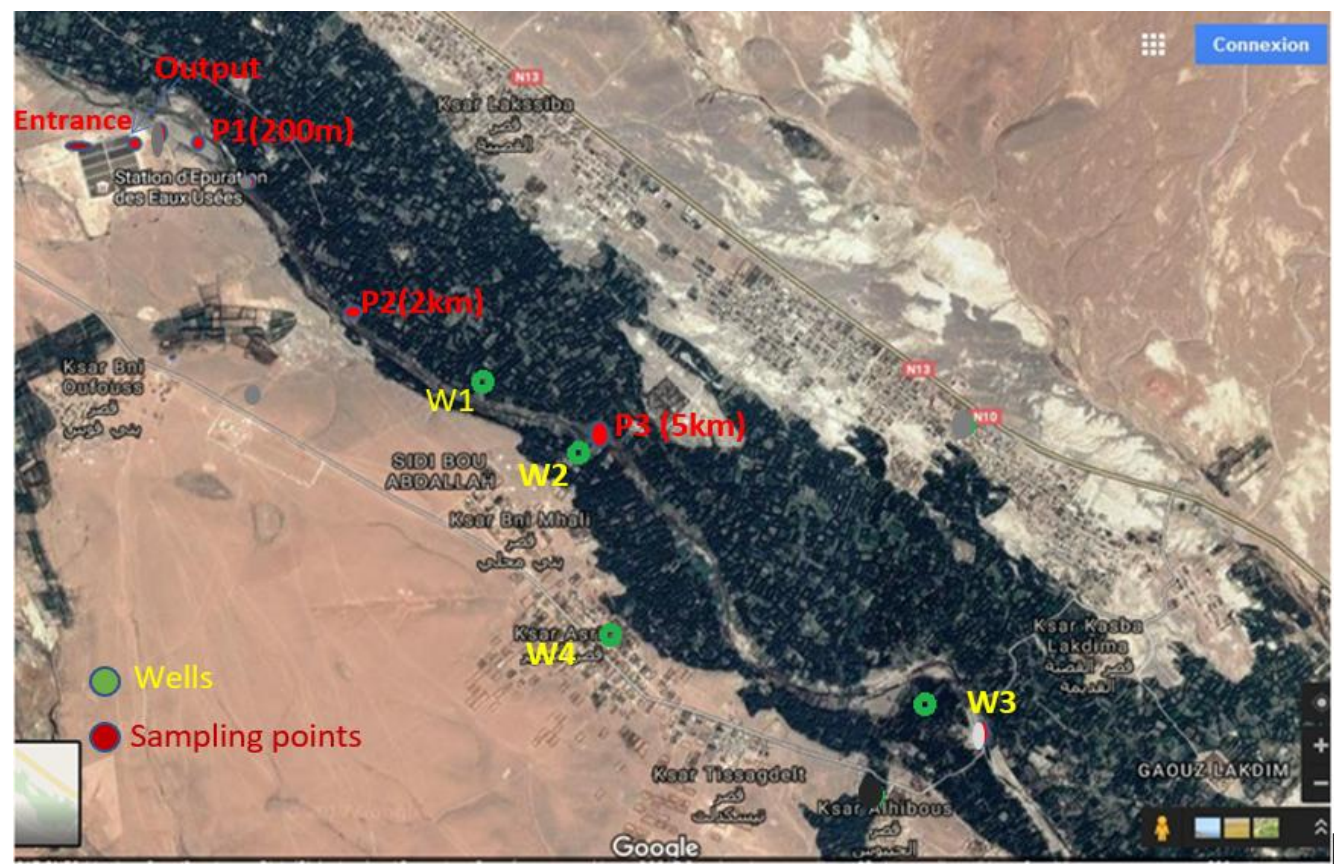

Fig-1: The Errachidia WWTPs location and sampling points in the Ziz valley

\section{Virus Concentration}

Raw sewage samples were first clarified by centrifugation of $500 \mathrm{ml}$ of wastewater at $1000 \mathrm{~g}$ for 5 $\min$ at $4^{\circ} \mathrm{C}$ and supernatant was used. The concentration method used in our study was an adaptation of previously described dead-end ultrafiltration protocol [12-14]. Briefly, each sample of $500 \mathrm{ml}$ was filtered through a cellulose nitrate filter of $0.2 \mu \mathrm{m}$ pore using the Sartolab® Vacuum Filtration Units from Sartorius ${ }^{\circledR}$. If the filter becomes clogged before the complete passage of $500 \mathrm{ml}$, we have used up to 3 filters in particular for the wastewater samples. Filters were then stored at $-80^{\circ} \mathrm{C}$ until analysis.

\section{Viral Nucleic Acids Extraction}

Each filter (or filter group) was divided aseptically on 2 sections. One of these was then inserted into a 2-ml screw-cap polypropylene tube containing $200 \mathrm{mg}$ of $106 \mu \mathrm{m}$ glass beads and $1 \mathrm{ml}$ of diluent buffer (Dulbecco's PBS with $0.01 \%$ Tween 80 and
$0.001 \%$ antifoam A). The tube was vortexed for $5 \mathrm{~min}$ at a high-speed setting. Then the sample was centrifuged at $5000 \mathrm{~g}$ for $2 \mathrm{~min}$ at $4^{\circ} \mathrm{C}$ and supernatant was used for the extraction. Influenza $\mathrm{A}(\mathrm{H} 1 \mathrm{~N} 1)_{\mathrm{pdm} 09}$ (INF) (strain (A/Rabat/HR1230/2010(H1N1) access number JX204762.1) was used as an external control to

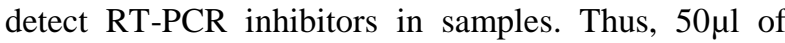
viral solution containing $100 \mathrm{TCID}_{50}$ (Tissue Culture Infective Dose) was added to each sample before nucleic acid extraction. Viral nucleic acids extraction was performed using the GeneJET Viral DNA/RNA Purification Kit (Thermo Fisher Scientific, Massachusetts, USA) according to the manufacturer's recommendations.

\section{VIRUS DETECTION METHODS}

One-step real-time RT-PCR was performed on Applied Biosystems ${ }^{\mathrm{TM}} 7500$ Real-Time PCR Systems (Thermo Fisher Scientific, Massachusetts, USA) using SensiFAST ${ }^{\mathrm{TM}}$ Probe Lo-ROX One-Step Kit (Bioline, 
Cincinnati, USA) with specific primers and probes previously reported for HEV, RV, NoV, HAV and INF (table 1). Real-time RT-PCR assays were carried out on duplex including Inf and an enteric virus at once. In a final volume of $20 \mu \mathrm{l}$, each reaction mixture contained $10 \mu 1$ of $2 X$ SensiFAST Probe Lo-ROX One-Step Mix, final concentrations of $0.4 \mu \mathrm{M}$ of each primer, $0.2 \mu \mathrm{M}$ TaqMan of each probe, $0.2 \mu$ l of Reverse transcriptase enzyme, $0.4 \mu \mathrm{l}$ of RiboSafe RNase Inhibitor, $1.8 \mu \mathrm{l}$ of water PCR grade and $4 \mu \mathrm{l}$ of template (sample extract, Positive/negative control). Real-time RT-PCR was performed under the following conditions: $10 \mathrm{~min}$ at $45^{\circ} \mathrm{C} ; 2 \mathrm{~min}$ at $95^{\circ} \mathrm{C}$; and 40 cycles of $5 \mathrm{sec}$ at $95^{\circ} \mathrm{C}$ and $20 \mathrm{sec}$ at $60^{\circ} \mathrm{C}$. All samples where the external control (inf) has not been amplified were retested at a dilution of $1 / 10$ and $1 / 100$.

Table-1:

\begin{tabular}{|l|l|l|c|}
\hline virus & Primers and probes & SEQUENCE (5'-3') & Reference \\
\hline & EV-UTR-F & ACATGGTGCGAAGAGTCTATTGAGCT & \\
\hline EV & EV-UTR-R & CGACTACTTTGGGTGTCCGTGTTTC & {$[15]$} \\
\hline & Probe & FAM-TCCGGCCCCTGAATGCGGCTAAT-BHQ1 & \\
\hline & HAV68 F & TCACCGCCGTTTGCCTAG & {$[16]$} \\
\hline HAV & HAV240 R & GGAGAGCCCTGGAAGAAAG & \\
\hline & Probe & FAM-CCTGAACCTGCAGGAATTAA-BHQ1 & {$[17]$} \\
\hline & QNIF4 F & CGCTGGATGCGNTTCCAT & \\
\hline NoV G I & NV1LCR R & CCTTAGACGCCATCATCATTTAC & {$[18]$} \\
\hline & Probe & FAM-TGGACAGGAGAYCGCRATCT-BHQ1 & \\
\hline NoV GII & QNIF2 F & ATGTTCAGRTGGATGAGRTTCTCWGA R & {$[19]$} \\
\hline & Probe & TCGACGCCATCTTCATTCACA & \\
\hline & JVK F & FAM-AGCACGTGGGAGGGCGATCG-TAMRA & \\
\hline RV & JVK R & CGATGGTTGATGCTCAAGATGGA & {$[20]$} \\
\hline & Probe & TCATTGTAATCATATTGAATACCCA & \\
\hline & INF F & FAM-ACAACTGCAGCTTCAAAAGAAGWGT-BHQ1 & \\
\hline Inf & INF R & CCMAGGTCGAAACGTAYGTTCTCTCTATC & \\
\hline & Probe & TGACAGRATYGGTCTTGTCTTTAGCCAYTCCA & \\
\hline
\end{tabular}

\section{RESULTS RT-PCR}

Specific RT-PCR assays chows that HEV and NoV were the most detected virus in samples with $100 \%$ of presence in the entrance and output of WWTPs with a persistence of detection in effluent and groundwater (table 2). RV was detected on 3 samples $(25 \%)$ at the entrance of the WWTPs and $41 \%$ in effluent of de treated wastewater were positive for RV. Contrariwise no HAV was detected in our study.

Concerning the effluent points, HEV were detected in all samples performed in the 3 points. The second prevalent viruses were NoV with a detection rate of $83 \%, 75 \%$ and $33 \%$ in P1, P2 and P3 respectively. Finally, RV was the least detected virus in this samples with a prevalence of $41 \%, 17 \%$ and $8 \%$ in $\mathrm{P} 1, \mathrm{P} 2$ and $\mathrm{P} 3$ respectively.

Viral research on groundwater reveals the presence of $\mathrm{HEV}$ in $58 \%, 50 \%, 67 \%$ and $100 \%$ of samples performed on $\mathrm{W} 1, \mathrm{~W} 2, \mathrm{~W} 3$ and $\mathrm{W} 4$ respectively. For other viruses, detection rates were $8 \%$ $, 8 \%, 16 \%$ and $83 \%$ for $\mathrm{NoV}$ and $0 \%, 8 \%, 0 \%, 67 \%$ for $\mathrm{RV}$ in $\mathrm{W} 1, \mathrm{~W} 2, \mathrm{~W} 3$ and $\mathrm{W} 4$ respectively.

As regards the distribution of positive samples according to the sampling season, we found that there was a season effect for the detection of enteric viruses, particularly at the points $\mathrm{P} 1, \mathrm{P} 2$ and P3. in fact, most of the positive results were detected on samples taken on cold season and when the river Ziz was dry and only the effluents from the treatment WWTPs were flowing.

As for the wells, the positive samples were detected mainly when the water table was at its lowest genotyping of the NoV strains showed that the vast majority of strains detected belonged to NoV GII with $84 \%$ of the positive samples. NoV GI was detected in only $4 \%$ of samples while $12 \%$ of samples were positive for both NoV GI-GII.

Table-2: The number of positive samples according to the sampling points (12 samples were performed for each point)

\begin{tabular}{|l|l|l|l|l|l|l|l|l|l|}
\hline Virus & Entrance of WWTPs & Output of WWTPs & $\begin{array}{l}\text { P1 } \\
\mathbf{5 0} \mathbf{~ m}\end{array}$ & $\begin{array}{l}\text { P2 } \\
\mathbf{2 5 0}\end{array}$ & $\begin{array}{l}\text { P3 } \\
\mathbf{5 0 0 m}\end{array}$ & $\mathbf{W 1}$ & W2 & W3 & W4 \\
\hline HEV & 12 & 12 & 12 & 12 & 12 & 7 & 6 & 8 & 12 \\
\hline RV & 3 & 5 & 5 & 2 & 1 & 0 & 1 & 0 & 8 \\
\hline NoV & 12 & 12 & 10 & 9 & 4 & 1 & 1 & 2 & 10 \\
\hline HAV & 0 & 0 & 0 & 0 & 0 & 0 & 0 & 0 & 0 \\
\hline
\end{tabular}




\section{DISCUSSION}

The aim of this study was to detect the presence of principal enteric viruses before and after disinfection processes of Errachidia's WWTPs and to evaluate environment contaminations by the final effluent. The results obtained show that ENV and NoV and, on a smaller scale, RT were very abundant in the station's effluents. This is a normal result insofar as that Errachidia's WWTPs does not include viral disinfection steps in its treatment process based on aerated lagoons. Even if most of the sanitizing treatments (chlorination, filtration, UV radiation) implemented throughout the world do not allow total elimination of enteric viruses, they nevertheless allow a significant reduction in the vial load at the level of effluents discharged into the environment [21-24]. Thus, the results obtained are consistent with the literature concerning the samples performed at the output of WWTPs especially for EV and NoV with $100 \%$ detection. Concerning the RV, we obtained detection rates of $42 \%$ at WWTPs output which was higher than that recorded at the entrance $25 \%$. This result is probably due to the difficulty of concentrating RVs from raw wastewater very loaded with organic materials.

The absence of HAV detection is most likely related to the absence of hepatitis A epidemic during the sample collection period. Indeed, the detection of $\mathrm{HAV}$ in water is quite rare if the samples are not taken during or immediately after hepatitis A epidemics [25, 26]. In addition, it should be remembered that the HAV has a very low concentration efficiency which allows the detection of its presence only during very high concentrations [27].

Concerning the sampling points along the wadi ziz, we note that all the samples were positive for EV. These results indicate that the viral load deflected by the effluents of the station is so high that neither the effect of the dilution nor the sanitizing effect of the sun's rays allowed a significant reduction in the presence of EV. Quantitative studies should make it possible to better assess the impact of these factors in reducing the amount of virus at each point.

For NoV, we noticed that the detection rate decreases according to a gradient of the distance from the point of discharge of the effluents of the station. These results could indicate that the viral load of Nov is low enough to be reduced by dilution in river water or other inactivating factors of the virus such as temperature or sunlight [28]. Concerning RV, the detection rate is lower than the previous viruses, but also with a gradient of distance from the point of effluent discharge. This result may also be due to the epidemic nature of rotavirus infections which concentrates the viral load mainly during cold seasons [29]. in fact, most $(76 \%)$ of the positive samples for the RV were carried out during the months of November-
March which shows that it is the virus most influenced by the season.

The second part of the study concerning the contamination of the water table through the evaluation of the contamination of 4 wells waters in the region. The interest of this study is due to the great influence that surface water has on the groundwater exploited through these wells. In fact, the constitution of the region soils is dominated by a sandy loam subsoil facilitating the infiltration of surface water. This is very visible in the results of the analyzes of wells W1, W2, and W3 where we noticed that the contamination of the water produced is correlated with the contamination of the surface points with a decrease in this contamination by moving away from the spill points of the WWTPs. thus, EV contamination is the most frequent with some detection of NoV and RV (Table-2).

The W4 well is a special case for which we noted a strong contamination by all enteric viruses. These results are probably related to the position of the well, which is located in a small village witch not have sanitation network and has recourse to septic tanks. It is probably the origin of the independent contamination of the WWTPs through the infiltration of water polluting in the water table.

\section{CONCLUSION}

This study provides the first findings on molecular detection of several enteric viruses on the effluents of a wastewater treatment plants in arid region of Morocco. The results obtained show that the water poured into the wadi $\mathrm{Ziz}$ is mainly contaminated by EV, $\mathrm{NoV}$ and RV. This contamination is also found in the groundwater table. This finding Suggest that the populations living on the riverside are exposed by water consumption, contaminated vegetables or recreational activities to gastrointestinal infections and diseases specially for children.

\section{REFERENCES}

1. Leclerc, H., Schwartzbrod, L., \& Dei-Cas, E. (2002). Microbial agents associated with waterborne diseases. Critical reviews in microbiology, 28(4), 371-409.

2. Sano, D., Amarasiri, M., Hata, A., Watanabe, T., \& Katayama, H. (2016). Risk management of viral infectious diseases in wastewater reclamation and reuse. Environment International, 91, 220-229.

3. Ahmad, T., Anjum, S., Afzal, M. S., Raza, H., Zaidi, N., \& Arshad, N. (2015). Molecular confirmation of enterovirus from sewage and drinking water samples from three cities, Pakistan: a potential risk factor for public health. The Southeast Asian J Trop Med Public Health, 46(4), 640-9.

4. Okoh, A. I., Sibanda, T., \& Gusha, S. S. (2010). Inadequately treated wastewater as a source of human enteric viruses in the 
environment. International journal of environmental research and public health, 7(6), 2620-2637.

5. Fernandez-Cassi, X., Timoneda, N., MartínezPuchol, S., Rusinol, M., Rodriguez-Manzano, J., Figuerola, N., ... \& Girones, R. (2018). Metagenomics for the study of viruses in urban sewage as a tool for public health surveillance. Science of the Total Environment, 618, 870-880.

6. Belguith, K., Hassen, A., \& Aouni, M. (2006). Comparative study of four extraction methods for enterovirus recovery from wastewater and sewage sludge. Bioresource technology, 97(3), 414-419.

7. Amdiouni, H., Faouzi, A., Fariat, N., Hassar, M., Soukri, A., \& Nourlil, J. (2012). Detection and molecular identification of human adenoviruses and enteroviruses in wastewater from Morocco. Letters in applied microbiology, 54(4), 359-366.

8. Smith, D. B., Paddy, J. O., \& Simmonds, P. (2016). The use of human sewage screening for community surveillance of hepatitis $E$ virus in the UK. Journal of Medical Virology, 88, 915-918.

9. Fong, E., \& Lipp, K. (2005). Enteric Viruses of Humans and Animals in Aquatic Environments: Health Risks, Detection, and Potential Water Quality Assessment Tools. Microbiology and Molecular Biology Reviews. DOI: 10.1128/MMBR.69.2.357-371.

10. Carducci, A., Morici, P., Pizzi, F., Battistini, R., Rovini, E., \& Verani, M. (2008). Study of the viral removal efficiency in a urban wastewater treatment plant. Water Science and Technology, 58(4), 893-897.

11. Hamid, C., Elwatik, L., Ramchoun, Y., FathAllah, R., Ayyach, A., Fathallah, Z., ... \& Hbaiz, E. M. (2014). Étude des performances épuratoires de la technique du lagunage aéré appliquée à la station d'épuration de la ville d'ErrachidiaMaroc. Afrique Science: Revue Internationale des Sciences et Technologie, 10(2):173-183.

12. Smith, C. M., \& Hill, V. R. (2009). Dead-end hollow-fiber ultrafiltration for recovery of diverse microbes from water. Applied and environmental microbiology, 75(16), 5284-5289.

13. Wu, J., Rodriguez, R. A., Stewart, J. R., \& Sobsey, M. D. (2011). A simple and novel method for recovering adenovirus 41 in small volumes of source water. Journal of Applied Microbiology, 110(5), 1332-1340.

14. Kahler, A. M., Johnson, T. B., Hahn, D., Narayanan, J., Derado, G., \& Hill, V. R. (2015). Evaluation of an ultrafiltration-based procedure for simultaneous recovery of diverse microbes in source waters. Water, 7(3), 1202-1216.

15. Cabrerizo, M., Calvo, C., Rabella, N., MuñozAlmagro, C., del Amo, E., Pérez-Ruiz, M., ... \& Trallero, G. (2014). Design and validation of a real-time RT-PCR for the simultaneous detection of enteroviruses and parechoviruses in clinical samples. Journal of virological methods, 208, 125128.

16. [16] M. Isabel Costafreda, Albert Bosch, and Rosa M. Pinto (Development, Evaluation, and Standardization of a Real-Time TaqMan Reverse Transcription-PCR Assay for Quantification of Hepatitis A Virus in Clinical and Shellfish Samples. APPL. ENVIRON. MICROBIOL. June 2006, p. 3846-3855.

17. da Silva, A. K., Le Saux, J. C., Parnaudeau, S., Pommepuy, M., Elimelech, M., \& Le Guyader, F. S. (2007). Evaluation of removal of noroviruses during wastewater treatment, using real-time reverse transcription-PCR: different behaviors of genogroups I and II. Applied and Environmental Microbiology, 73(24), 7891-7897.

18. Loisy, F., Atmar, R. L., Guillon, P., Le Cann, P., Pommepuy, M., \& Le Guyader, F. S. (2005). Real-time RT-PCR for norovirus screening in shellfish. Journal of virological methods, 123(1), 1-7.

19. Jothikumar, N., Kang, G., \& Hill, V. R. (2009). Broadly reactive TaqMan ${ }^{\circledR}$ assay for real-time RT-PCR detection of rotavirus in clinical and environmental samples. Journal of virological methods, 155(2), 126-131.

20. Anonymous. WHO information forthe molecular detectionof influenza viruses. https://www.who.int/influenza/gisrs_laboratory/W HO_information_for_the_molecular_detection_of _influenza_viruses_20171023_Final.pdf

21. Rose, J. B., Nowlin, H., Farrah, S. R., Harwood, V. J., Levine, A. D., Lukasik, J., Menendez, P., \& Scott, T. M. Reduction of Pathogens, Indicator Bacteria, and Alternative Indicators by Wastewater Treatment and Reclamation Processes. Water Environment Research Foundation and IWA Publishing, Denver, CO, USA. Available from: https://www.werf.org/a/ka/Search/ResearchProfile .aspx?ReportId=00-PUM-2T

22. Wong, M. V., Hashsham, S. A., Gulari, E., Rouillard, J. M., Aw, T. G., \& Rose, J. B. (2013). Detection and characterization of human pathogenic viruses circulating in community wastewater using multi target microarrays and polymerase chain reaction. Journal of water and health, 11(4), 659-670.

23. Kingsley, D. H., Fay, J. P., Calci, K., Pouillot, R., Woods, J., Chen, H., ... \& Van Doren, J. M. (2017). Evaluation of chlorine treatment levels for inactivation of human norovirus and MS2 bacteriophage during sewage treatment. Applied and environmental microbiology, 83(23):e0127017.

24. Simhon, A., Pileggi, V., Flemming, C. A., Bicudo, J. R., Lai, G., \& Manoharan, M. (2019). Enteric viruses in municipal wastewater effluent before 
and after disinfection with chlorine and ultraviolet light. Journal of water and health, 17(5), 670-682.

25. Souza, F. G. D., Silva, F. P. D., Staggemeier, R., Rigotto, C., \& Spilki, F. R. (2018). Low occurrence of Hepatitis A virus in water samples from an urban area of Southern Brazil. Revista do Instituto de Medicina Tropical de São Paulo, 60:e69.

26. Schlindwein, A. D., Rigotto, C., Simões, C. M. O., \& Barardi, C. R. M. (2010). Detection of enteric viruses in sewage sludge and treated wastewater effluent. Water Science and Technology, 61(2), 537-544.
27. Qiao, Y., Sui, Z., Hu, G., Cao, H., Yang, G., Li, Y., ... \& Chen, Q. (2016). Comparison of concentration methods for detection of hepatitis A virus in water samples. Virologica Sinica, 31(4), 331-338.

28. Xagoraraki, I., Yin, Z., \& Svambayev, Z. (2014). Fate of viruses in water systems. Journal of Environmental Engineering, 140(7), 04014020.

29. Viviana, B., Viviane, G., Sonia, P., Andrés, L., Luis, F. López, T., \& Fernando, R. S. (2020). Detection, Quantification, and Microbial Risk Assessment of Group A Rotavirus in Rivers from Uruguay. Food Environ Virol. 12(2):89-98. 